\title{
Genders in Speed Reading; A Comparative Study at the Forth Semester Students in Faculty of Culture, Management, and Business Language Education Mandalika University Of Education
}

\author{
Terasne $^{1}$, Tri Setianingsih ${ }^{2}$ \\ ${ }^{12}$ Faculty of Culture, Management, and Business, Language Education \\ Mandalika University of Education \\ terasne@ikipmataram.ac.id; trisetianigsih@ikipmataram.ac.id
}

\begin{abstract}
Genders in Speed Reading; A Comparative Study at the Forth Semester Students in Faculty of Culture, Management, and Business, Language Education, This study aimed to compare male and female students' ability in speed reading. The population of this study were the forth semester students at Faculty of Culture, Management, and Business, Language Education Mandalika University of Education in academic year 2020/2021. There were 60 students as the sampleof the study in which divided into class IV for male consisted of 30 students and class $I V^{B}$ for female consisted of 30 students. Data wascollected by using timed reading. The data were analyzed and interpreted statistically by using a comparative method. They study found that both students ability in speed reading male and female, was bad. They are very slow readers. The data showed 11 out of 30 male students (37\%) are categorized to be low readers and-19 out of 30 male students (63\%) was categorized as very slow readers. Similarly 8 out of 30 female students (27\%) were categorized as low readers and 22 out of 30 female students (73\%) are categorized as very slow readers. There were no significant differences between genders in speed reading. The study shows the t-testvalue 0.298 was lower than t-table values of 2.000 at confidence level $95 \%$ and 2.660 at confidencelevel $99 \%$.
\end{abstract}

\section{Keywords: Genders In Speed Reading}

\begin{abstract}
Abstrak. Penelitian ini bertujuan untuk mebandingkan kemampuan membaca cepat mahasiswa putra dan putri. Populasi penelitian ini adalah mahasiswa semester IV Fakultas Kebudayaan, Manajemen, dan Bisnis Pendidikan Bahasa Universitas Pendidikan Mandalika tahun ajaran 2020/2021. Sampel penelitian berjumlah 60 siswa yang terbagi dalam kelas IV ${ }^{\mathrm{A}}$ untuk siswa laki-laki sebanyak 30 oarang dan kelas IV $^{\mathrm{B}}$ untuk siswa perempuan sebanyak 30 oarang. Data dikumpulkan dengan menggunakan membaca berjangka waktu. Data dianalisis dan diinterpretasikan secara statistik dengan menggunakan metode komparatif. Peneliti menemukan bahwa kemampuan membaca cepat siswa laki-laki dan perempuan, buruk. Siwa adalah pembaca yang sangat lambat. Data menunjukkan 11 dari 30 siswa laki-laki (37\%) masuk kategori pembaca rendah dan-19 dari 30 siswa laki-laki (63\%) masuk kategori pembaca sangat lambat. Demikian pula 8 dari 30 siswa perempuan (27\%) dikategorikan pembaca rendah dan 22 dari 30 siswa perempuan (73\%) dikategorikan pembaca sangat lambat. Tidak ada perbedaan yang signifikan antara jenis kelamin laki-laki dan perempuan dalam membaca cepat. Hasil penelitian menunjukkan nilai t-test 0.298 lebih rendah dari nilai t-tabel 2.000 pada tingkat kepercayaan $95 \%$ dan 2.660 pada tingkat kepercayaan $99 \%$.
\end{abstract}

Kata Kunci: Jenis Kelamin Dalam Membaca Cepat

\section{INTRODUCTION}

Reading in a First Language is usually different from reading in a Second Language. Students in their experience usually find out that reading in the first language is much easier than that of the second language because they have mastered the vocabulary and the structure of their own language. Reading English texts are usually difficult for the at forth semester students who joint such extensive reading as compulsory subject matter by requiring the students to read a books as much as better in one semester. On the other hand, the students fled board to read
English books it is sometimes because of there were only view English book with new words and the students are come form different background such male and female students who have different speed in reading texts. These facts faced by the at Faculty of Culture, Management, and Business, Language Education Mandalika University of Education the students read English text from the text book. They are required to have adequate knowledge of the language which has a different system, including vocabulary and structure. Therefore, they tend to fail to understand the text comprehensively. Student 
who have mastered enough vocabulary and have understood structure have no significant difficulties when reading texts in the second language. The aim of teaching reading at university is to develop the students reading skills, so that they can read English text effectively and efficiently. Abdurrahman, A. (2013) stated in his book that, to be effective readers, students should be able to scan (glance at the text to get specific information), skim (glance at the text to the gist of the text or the main point), read between the lines, read intensively for detailed information, detect references (referring the text), and deduce meaning from the text. It is certainly not easy to present the English reading to Indonesian students for the linguistic system of English is different from the Indonesian ones. Reading as language skill plays an important role in language learning. In term of reading skills, teacher or lecturer should considermany things such as: facilities, students' background knowledge and teaching method. Moreover, to understand a text, a student must have a good explanation of the vocabulary of the target language because vocabulary proficiency enables the students to acquire the skills of listening, speaking, reading and writing. Infect, they rarely read English text because there are not enough English books. Such as that condition, the researchers interested to make a study entitled "a comparative study on genders in speed reading at the forth semester students in Faculty of Culture, Management, And Business, Language Education, Mandalika University of Education.

\section{RESEARCH METHODS}

The kind of this study was a comparative study, the method used was comparative analysis method. The researchers give to the students some questions in the passage to compare the students' ability in speed reading between female and male by identifying genders and speed reading.

\section{Population and sample}

The population of this study were the forth semester students at Faculty of Culture, Management, and Business Language education in academic year 2020/2021. They were divided in to two classes consisting of class $\mathrm{IV}^{\mathrm{a}}$ for male student and $\mathrm{IV}^{\mathrm{B}}$ for female students consisted of 30 students in each class. It means that there were 60 students in total. If the students more than 100 we will take some sample but if the students less than 100 it better take all as the sample. So in this study, the researchers took all of the population as the sample (Arikunto S., 1997).

\section{Instruments}

Instrumnets in study used reading comperhesion texts in the form of timed reading passage consists of 300 words and consists of 10 items of multiple choices. On the text enttled" Smoking is degrous for lung".

\section{Technique of data collection}

In this study, to collect the data the researchers used was timed reading kind of the test of speed reading as an instrument. The time of speed reading was: 1,00,.2,00.,3,00.,4,00.,5,00.,7,00.,8,00.,9,00., and 10,00 . Timed reading passage consists of 300 words and consists of 10 items in the form of multiple choices. Then the researcher gives the some instructions how to do speed reading the students were: (1) reading the passage as fast as possible; (2) read in their mind; (3) keep on reading when finding the difficult word, ignore them; (4) copy the time which the writer points on the blackboard, then answer the questions of reading directly without looking back to the reading passage. To get the timing reading, the researchers writes the time of reading speed as following on the blackboards. The researchers controlled the timing and explain the time of speed reading on the blackboard for the students before the students start their activities. Every student should answer the question of the reading passage. Then, each of the students finishes to answering the question, students write the time of their own base on the timing on the board. In analyze the data, the researchers' accounts total number of words perminute which was read by the students as follow:

The amount of words read

$$
\text { 1. ...X } 60=\ldots . . \mathrm{WPM}
$$

Time of reading needed in second 
In where:

1. Words per minute of male/female students $\mathrm{WPM}=$ Words per Minute

For scoring the result of reading comprehension test, the uses the formula as following formula:
a. $S_{a}=$ correct answers
X 100
b. $\mathrm{S}_{\mathrm{b}}=$ correct answer
X 100

In where:

$\mathrm{S}_{\mathrm{a}}=$ score of male students

$\mathrm{Sb}=$ score of female students

The data that was use to test the hypothesis was combed by using formula. The aim of this research is to find out the differences between two variables. The step of analysis drawn below.

$$
\begin{gathered}
\bar{X}=\frac{\sum}{N x} \\
\bar{Y}=\frac{\sum Y}{N y}
\end{gathered}
$$

In where,

$$
\begin{aligned}
& \sum \begin{array}{l}
\sum \\
\bar{X}=\text { The sum of } \\
\text { students }
\end{array} \\
& \overline{\mathrm{Y}}=\text { Means score achieved of female } \\
& \quad \text { students } \\
& S=\text { Standard Deviation } \\
& N=\text { Number of sample }
\end{aligned}
$$

If the score of ratio t-test is higher than $\mathrm{t}$ table, it means that the differences of the those variable are significant, it means that first hypothesis (Ha: $X \neq Y$ ) iwas accepted and another hypothesis $(\mathrm{Ho} ; \mathrm{X}=\mathrm{Y})$ is rejected.

\section{FINDING AND DISCUSSION}

The result of data obtained on speed reading and reading comprehension score of second year students in the Forth Semester Students at Faculty of Culture, Management, and Business, Language Education as samples of this study. The data were as following: 1 . The male students individual score of WPM (Word Per Minute) are presented in the following chart below:

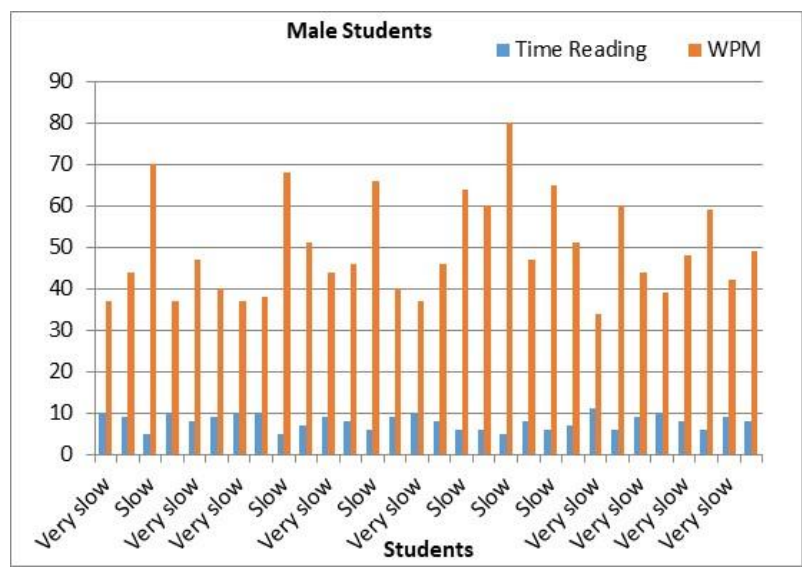

Chart 1. Male Students

Table 1. The categories of male student in speed reading

\begin{tabular}{c|c|c|c|c|}
\hline No & Categories & Limit & [Students & $\%$ \\
\hline 1 & Very fast & $400-700$ WPM & 0 & - \\
\hline 2 & Fast & $200-399$ WPM & 0 & - \\
\hline 3 & Average & $100-199$ WPM & 0 & - \\
\hline 4 & Slow & $50-99$ WPM & 11 & $37 \%$ \\
\hline 5 & Very Slow & $0-50$ WPM & 19 & $63 \%$ \\
\hline
\end{tabular}

Referring to the table above, the students who are WPM (Word Per Minute) between 50 - 100 WPM are 11 students. They are Ns $(3,9,10,13,17,18,19,21,22,24,28)$ and by looking at their WPM, the category of their speed reading as slow with $37 \%$ of students. Then, the students who are WPM (Word Per Minute) 0-50 WPM as 19 students. They are Ns $(1,2,4,5,6,7,8,11,12,14,15,16,20,23,25,26,27,29$,

3 ) and the category of their speed reading as Very slow. It could be said that $63 \%$ of the male students are classified as very slow readers. The female students individual score of WPM (Word Per Minute) are presented in the following chart below:

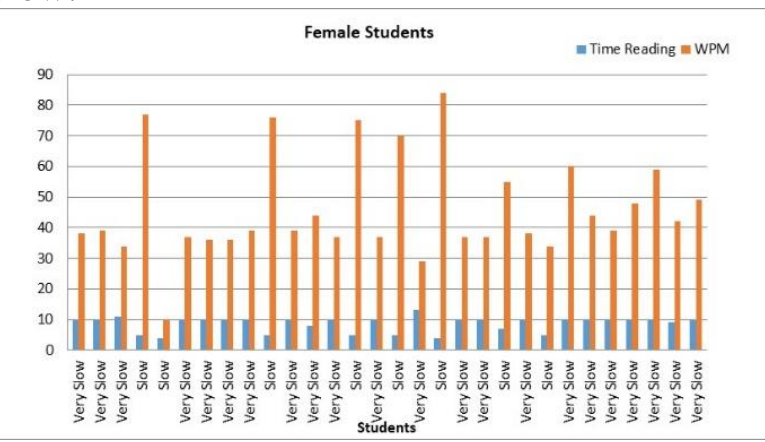

Chart 2. Female students 
Table 2. The categories of female students in

\begin{tabular}{|c|c|c|c|c|}
\hline No & Categories & Limit & $\Sigma$ & $\%$ \\
\hline 1 & Very fast & $400-700$ & 0 & - \\
\hline 2 & Fast & $200-399$ & 0 & - \\
\hline 3 & Average & $100-199$ & 0 & - \\
\hline 4 & Slow & $50-99$ WPM & 8 & $27 \%$ \\
\hline 5 & Very slow & $0-49$ WPM & 22 & $73 \%$ \\
\hline
\end{tabular}

Referring to the table above, the students who are WPM (Word Per Minute) between 50100 WPM are 8 students. They are Ns ( $4,5,10,14,16,18,21,23$ ) and by looking at their WPM, the category of their speedreading as slow with $27 \%$. Then, the student s who are WPM 049 WPM are 22 students. They are Ns $(1,2,3,6,7,8,8,11,12,13,15,17,19,20,22,24,25,26$, $27,28,29,30)$ and the category of their speed reading as very slow. This means that $73 \%$ of the female students are categories as very slow readers. This table indicates that are categorized of speed reading of male and female students as very slow readers. The graph show that the circle in under line 49 WPM (Word Per Minute) as very slow reader with low comprehension. And the students get the circle in upper line 49 WPM (Word Per Minute) are categorized as low readers with low comprehension.

Referring to the table above, the students who are WPM (Word Per Minute) between 50100 WPM are 8 students. They are Ns $4,5,10,14,16,18,21,23)$ and by looking at their WPM, the category of their speedreading as slow with $27 \%$. Then, the student s who are WPM 049 WPM are 22 students. They are Ns $(1,2,3,6,7,8,8,11,12,13,15,17,19,20,22,24,25,26$, $27,28,29,30)$ and the category of their speed reading as very slow. This means that $73 \%$ of the female students are categories as very slow readers. This table indicates that are categorized of speed reading of male and female students as very slow readers. The graph show that the circle in under line49 WPM (Word Per Minute) as very slow reader with low comprehension. And the students get the circle in upper line 49 WPM (Word Per Minute) are categorized as low readers with low comprehension.

The calculation of standard deviation measure of variability calculation around the mean. This study uses 60 sample students who were divided two classes. Then, the standard deviation score of the two classes was calculated by using the followingformula:
Tabel 3. Descriptive statistics

\begin{tabular}{ccccc}
\hline M/F & Minimum & Maximum & Mean & $\begin{array}{l}\text { Std. } \\
\text { Deviation }\end{array}$ \\
\hline 30 & 1501.2 & 4119.34 & 50.1 & 58 \\
\hline 30 & 1438.8 & 8634.52 & 48 & \\
\hline 60 & 6.74 & 16.97 & & \\
\hline \multicolumn{5}{c}{ Not find certain degree of freedom for 58 }
\end{tabular}

then took the nearest one was 60 . Found out the result was t-table on df 60 under the confidence level of $99 \%$ or $(2.660)$ and $95 \%$ or (2.000). It is concluded that the degrees of the two deviation value of twovariables.

a. The alternative hypothesis (Hi) which reads "there is a significant difference between the male and female students in speed reading" $(\mathrm{Hi}: \mathrm{X} \neq Y)$.

b. Then the null hypothesis (Ho) which reads "there is no difference between male and female students in speed reading " $(\mathrm{Ho}: \mathrm{X}=\mathrm{Y})$ is accepted.

c. Factors difference gender in speed reading is the speed reading between male and female student is not so difference because male and female the same for reading.

\section{CONCLUSION}

Both of male and female students' ability in speed reading was very slow readers. It means that there were no differences between male and female in speed reading at the forth semester students at Faculty of Culture, Management, and Business Language education in academic year 2020/2021

\section{SUGGESTIONS}

The teachers or a lecturer who teaches reading at Faculty of Culture, Management, and Business, Language Education Mandalika University of Education should give opportunity to their students to choose interesting topics so that they do not feel bored and enjoy their reading, it is a good reading exercise for the students on speed reading.

\section{ACKNOWLEDGMENTS}

The research team would like to thank goes to Dean, Students who joint Extensive Reading in Forth semester $\mathrm{VI}^{\mathrm{a}}$ and $\mathrm{IV}^{\mathrm{b}}$, lecturers and all Staff at the Faculty of Culture, Management, and the University of Education (UNDIKMA) Mataram through this research and 
Terakreditasi Peringkat 4 (No. SK: 36/E/KPT/2019)

providing us opportunities and facilitated our activities so that they can run well.

\section{REFERENCES}

Abdurrahman, A. (2013). Thesis an Exploration and Interpretation of Popular Method in Language in The Indonesian Language.

Arikunto, S. (1997). Prosedur Penelitian Suatu Pendekatan Praktek. Jakarta ; PT RinekaCipta.

Donought and Saw (2016). The study of Language. $\quad 2^{\text {nd }} \quad$ Revision Cambrige: Harvard

University Press.

Gibson and Levin, (2014). The ABC's of Language and Linguistic. $3^{\text {rd }}$ Revision,

Philadelphia :Chilton Company.

Gibson and Levin, (2014). The ABC's of Language and Linguistic. $3^{\text {rd }}$ Revision,

Philadelphia :Chilton Company.

Harris, Marvin. (2013). Culture People Nature: An Introduction To General Anthropology. New York: Harper Collins College Publihers.

Ma'ruf, Fakhriel. (2015). A Thesis The Corelation Between The Reading Speed and ReadingComprehension.

Manicas and Klinger. (2015). Logic:

The Essential. New York: Mc GrawHil,inc.

Mckenzi, Janet. (2001). Changing Education : A Sociology of Education Since 1994. England: Prentice Hall

Murdase, L. (2017). the Use Of Modified Text In Teaching Reading for The Second Year Student of Mts.Al Khairiyah NW Mujur In Academic Year 1999/2000. FKIP; Unram

Williams (2018). Timed Reading. Rhode Island: James TownPublisher. 